\title{
PI (phosphoinositide)-3 Kinase Assay
}

Huan Pang*

Molecular Pharmacology, Albert Einstein College of Medicine, Bronx, USA

*For correspondence: pang huan@hotmail.com

[Abstract] PI3-kinases regulate a wide range of cellular responses through the production of phosphatidylinositol 3, 4, 5-trisphosphate $[\mathrm{PI}(3,4,5) \mathrm{P}(3)]$ in cellular membranes. This protocol provides a highly efficient and easy-to-handle method for sensitive detection and quantification of PI 3-kinase activity.

\section{Materials and Reagents}

1. Tris

2. $\mathrm{NaCl}$

3. EDTA

4. Triton-X100

5. Glycerol

6. $\mathrm{NaF}$

7. PMSF

8. Aprotinin

9. Leupeptin

10. Sepharose

11. NP-40

12. Tris-LiCl

13. TNE

14. $\mathrm{P}^{32}$ hot ATP (PerkinElmer, catalog number: NEG502A)

15. $\mathrm{MgCl}_{2}$

16. $\mathrm{MnCl}_{2}$

17. EGTA

18. Methanol

19. Chloroform

20. Acetic acid

21. Isopropanol

22. Lysis buffer

23. Pre-washed sepharose 
24. ATP mix (see Recipes)

25. Phosphoinositol lipid (Avanti Polar Lipid, catalog number: 190082) (see Recipes)

\section{Equipment}

1. Centrifuges

2. Sonicator

3. Radiation hood

4. Silica gel TLC plate

\section{Procedure}

1. Lyse the cell with cantley lysis buffer plus protease inhibitor (aprotinin $100 \mu \mathrm{g} / \mathrm{ml}$, Leupeptin $1 \mu \mathrm{g} / \mathrm{ml}$, PMSF $35 \mathrm{mg} / \mathrm{ml}$ ), spin at 10,000 $\times \mathrm{g}$ for $15 \mathrm{~min}$.

2. Take the supernatant after centrifugation. Immunoprecipitate with the antibody against protein of interest at $4{ }^{\circ} \mathrm{C}$ on wheel overnight.

3. Add $60 \mu \mathrm{l}$ pre-washed sepharose (either protein A or protein $\mathrm{G}$ ) with cut pipet tips to each sample. Put on wheel at $4{ }^{\circ} \mathrm{C}$ for 2-3 $\mathrm{h}$.

4. Spin the sample, (you might want to save the supernatant for future analysis). Wash the samples extensively with following:

a. $3 \times 1 \mathrm{ml}$ wash with PBS-1\% NP-40

b. $3 \times 1 \mathrm{ml}$ wash with Tris- $\mathrm{LiCl}$

c. $2 \times 1 \mathrm{ml}$ wash with TNE

Make sure the washes will not sit at room temperature (RT) for long. Add $60 \mu \mathrm{l}$ TNE to each sample.

5. Return the samples on ice while preparing substrates for the assay:

For each sample phosphoinositol lipid, ATP mix and $100 \mathrm{mM} \mathrm{MgCl} 2$ or $\mathrm{MnCl}_{2}$ is needed.

6. After preparing all the reagents, add $10 \mu \mathrm{l}$ of PI lipid and $10 \mu \mathrm{l}$ of $10 \mathrm{mM} \mathrm{MgCl}_{2}$ to each sample. Now you are ready to perform the assay in the radiation hood.

7. Add hot ATP in the hood. Start the assay by adding $5 \mu$ ATP mix to the sample $10 \mathrm{sec}$ apart and stop each reaction with $20 \mu \mathrm{l}$ of $8 \mathrm{M} \mathrm{HCl}$ when reach $10 \mathrm{~min}$.

Note: make sure to mix the reaction well for each addition.

8. Add $160 \mu \mathrm{l}$ of 1:1 methanol: chloroform to extract lipid and mix well.

9. Spin the samples in the hot centrifuge for $5 \mathrm{~min}$, remove the upper (water) phase.

10. Wash the organic layer twice with $200 \mu \mathrm{l} 1 \mathrm{M} \mathrm{HCl}$.

11. Spot adequate amount of washed chloroform phase onto a silica gel TLC plate (the sample can be stored at $-70^{\circ} \mathrm{C}$ if not spotting). 
12. Run the plate in the solvent mix (2 M acetic acid/isopropanol 1:2) tank until the solvent front is about $2-3 \mathrm{~cm}$ away from the top.

13. Take out the plate and dry in the hood.

14. Wrap the plate and expose on the film at $-70^{\circ} \mathrm{C}$ overnight.

15. Quantify the phosphatidylinositol3-phosphate spots.

\section{$\underline{\text { Recipes }}$}

For example, if you have 10 samples prepare the reagents as following: Put two extra in: $10+2=12$ samples.

1. PI lipid

$2 \mu \mathrm{l} \times 12$ samples $=24 \mu \mathrm{l}$

Take out $24 \mu \mathrm{PI}$, dry under the Argon. Bring up to $120 \mu \mathrm{l}$.

$10 \mathrm{mM}$ Tris and $1 \mathrm{mM}$ EGTA.

Sonicate $10 \mathrm{~min}$.

2. ATP Mix

Need total volume $5 \mu \mathrm{l} \times 12$ samples $=60 \mu \mathrm{l}$ ATP Mix

$12 \mu \mathrm{l}$ hot ATP $(10 \mathrm{uCi} / \mu \mathrm{l})$

$12 \mu$ Cold $10 \mathrm{mM}$ ATP

$36 \mu \mathrm{H} \mathrm{H}_{2} \mathrm{O}$

3. $\mathrm{MgCl}_{2}$

$10 \mu \mathrm{l} \times 12$ samples $=120 \mu \mathrm{l}$ total

\section{References}

1. Wu, H., Shekar, S. C., Flinn, R. J., El-Sibai, M., Jaiswal, B. S., Sen, K. I., Janakiraman, V., Seshagiri, S., Gerfen, G. J., Girvin, M. E. and Backer, J. M. (2009). Regulation of Class IA PI 3-kinases: C2 domain-iSH2 domain contacts inhibit p85/p110alpha and are disrupted in oncogenic p85 mutants. Proc Natl Acad Sci U S A 106(48): 20258-20263.

2. Yip, S. C., El-Sibai, M., Hill, K. M., Wu, H., Fu, Z., Condeelis, J. S. and Backer, J. M. (2004). Over-expression of the p110beta but not p110alpha isoform of PI 3-kinase inhibits motility in breast cancer cells. Cell Motil Cytoskeleton 59(3): 180-188. 